\title{
Review Article \\ Recent Strategy of Biodiesel Production from Waste Cooking Oil and Process Influencing Parameters: A Review
}

\author{
A. Gnanaprakasam, V. M. Sivakumar, A. Surendhar, \\ M. Thirumarimurugan, and T. Kannadasan \\ Department of Chemical Engineering, Coimbatore Institute of Technology, Coimbatore, Tamil Naclu 641 014, India \\ Correspondence should be addressed to V. M. Sivakumar; vmsivakumar@gmail.com
}

Received 25 February 2013; Revised 11 April 2013; Accepted 22 April 2013

Academic Editor: S. Venkata Mohan

Copyright (c) 2013 A. Gnanaprakasam et al. This is an open access article distributed under the Creative Commons Attribution License, which permits unrestricted use, distribution, and reproduction in any medium, provided the original work is properly cited.

Cost of biodiesel produced from virgin vegetable oil through transesterification is higher than that of fossil fuel, because of high raw material cost. To minimize the biofuel cost, in recent days waste cooking oil was used as feedstock. Catalysts used in this process are usually acids, base, and lipase. Since lipase catalysts are much expensive, the usage of lipase in biodiesel production is limited. In most cases, $\mathrm{NaOH}$ is used as alkaline catalyst, because of its low cost and higher reaction rate. In the case of waste cooking oil containing high percentage of free fatty acid, alkaline catalyst reacts with free fatty acid and forms soap by saponification reaction. Also, it reduces the biodiesel conversions. In order to reduce the level of fatty acid content, waste cooking oil is pretreated with acid catalyst to undergo esterification reaction, which also requires high operating conditions. In this review paper, various parameters influencing the process of biofuel production such as reaction rate, catalyst concentration, temperature, stirrer speed, catalyst type, alcohol used, alcohol to oil ratio, free fatty acid content, and water content have been summarized.

\section{Introduction}

Fuels, generated from biological feed stocks, are termed as "biofuels." In general, biofuels can be broadly classified into first-generation fuels and second-generation fuels. First generation fuels or conventional biofuels are generally derived from sugar, starch, and vegetable oil source. Whereas, second-generation biofuels are generated from sustainable feedstocks. The major classification of biofuels is shown in Figure 1.

Because of high viscous nature, direct application of vegetable oil as a fuel in compression ignition engines has been limited [1]. It is possible to reduce its viscosity by converting vegetable oil into alkyl esters using transesterification reaction [2-4]. Nowadays, biodiesel production has been increased enormously to compete with fossil fuels. The production of biodiesel in recent years around the world is shown in Figure 2. Biofuels are mostly derived from edible oil, nonedible oil, fats, waste cooking oil, and algae. Advantage of using virgin vegetable oil (edible oil) as raw material for production of biodiesel is their low free fatty acid content [5]. Similarly, the main advantage of biodiesel synthesis over nonedible oil source is due to their high free fatty acid content [6].

Instead of using virgin vegetable oil, waste cooking oil can be used as raw material for biodiesel production [8]. In most of hotels, restaurants, and in other food industries, the waste cooking oil is either simply discharged into the river or dumped into the land. Inspite of this, the waste cooking oil can be used effectively for the biodiesel synthesis. Biodiesel production from waste cooking oil is found to be economically feasible method [9]. Different sources of raw material used for the production of biodiesel are shown in Figure 3. The property of biodiesel depends on the type of fresh cooking oil used [10]. Biodiesel can also be blended with mineral oil [11]. Even the wastes (byproducts) generated from biodiesel production can be used for power production [12]. 


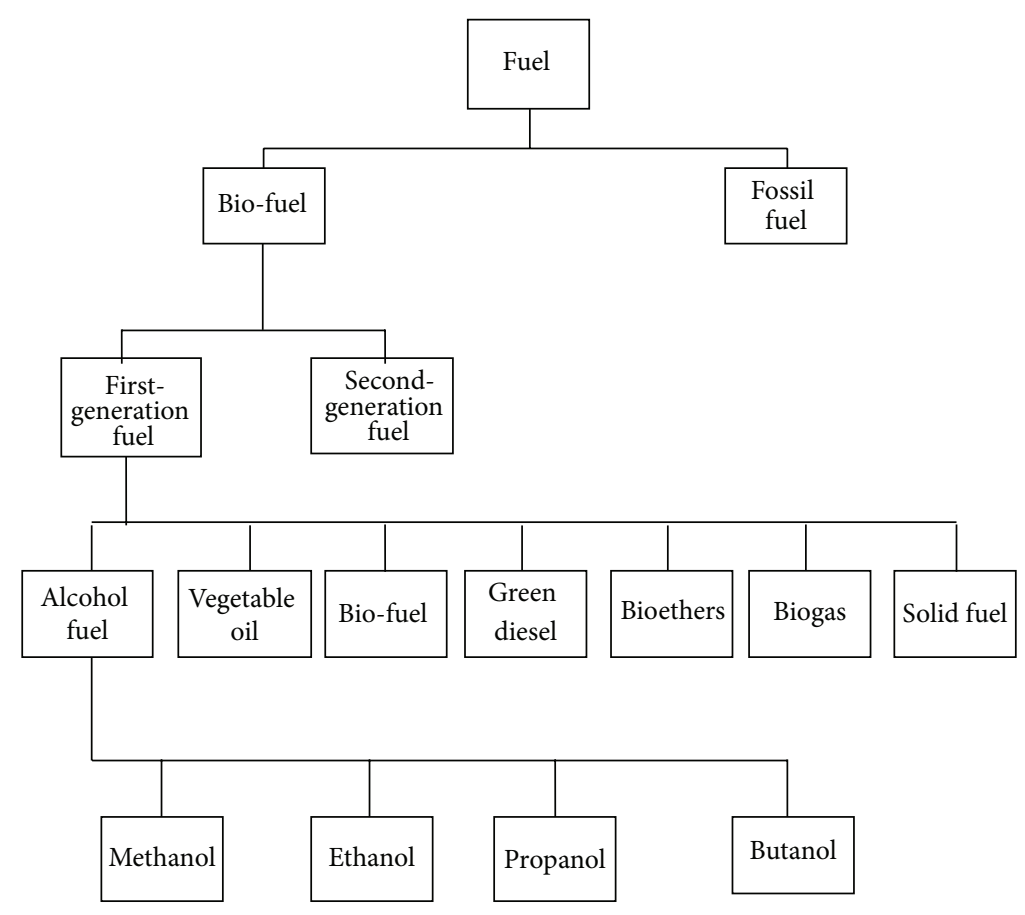

FIGURE 1: Classification of biofuels.

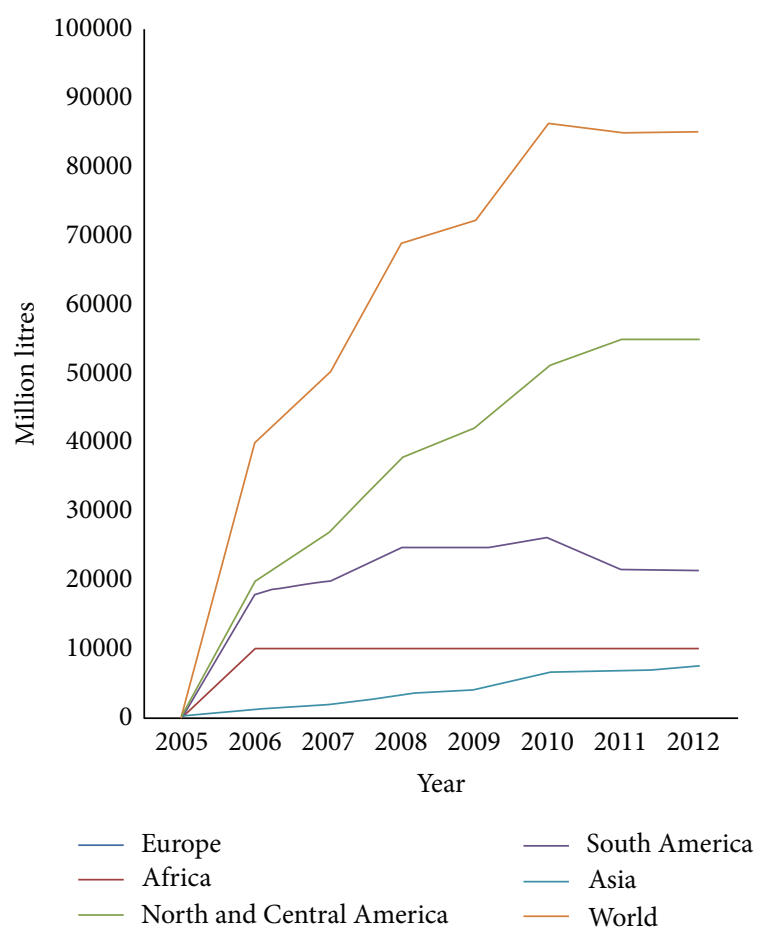

FIgURE 2: Production of biodiesel in recent years [7].

\section{Basic Reaction Mechanism Involved in the Production of Biodiesel}

2.1. Transesterification. The major component of vegetable oil is triglycerides. When the triglycerides react with alcohol

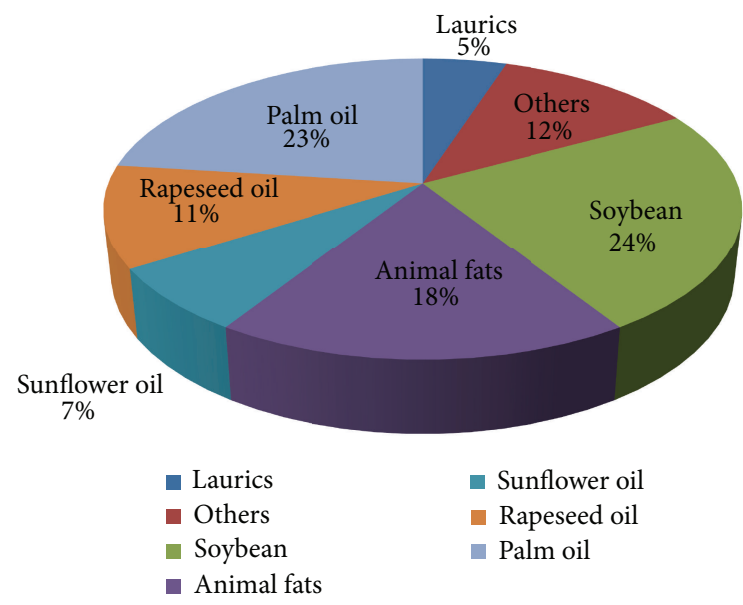

Figure 3: Production of biodiesel from different feed stock [13].

in the presence of base catalyst, this is called "transesterification." In this reaction, triglycerides are converted to diglyceride, monoglyceride, and finally converted to glycerol. The reaction mechanism is shown in Scheme 1.

2.2. Side Reaction 1 (Saponification Reaction). If vegetable oil contains free fatty acid, it will react with homogenous base catalyst to form soap and water. The saponification reaction is represented as shown in Scheme 2.

The main drawback in this reaction is the consumption of catalyst and increased difficulty in separation process, which leads to high production cost. In addition to that, formation of water in the product will also inhibit the reaction. 
<smiles>[R]OC(=O)OCC(COC([R])=O)OC([R])=O</smiles>

Triglyceride<smiles>OCC(O)C(O)CO</smiles><smiles>[R]OC(=O)OCC(C)OC([R])=O</smiles>

Alcohol
Glycerol

SCHEME 1

$$
\mathrm{R}_{1}-\mathrm{COOH}+\mathrm{NaOH} \longrightarrow \mathrm{R}_{1} \mathrm{COONa}+\mathrm{H}_{2} \mathrm{O}
$$

FFA Sodium hydroxide Soap Water

SCHEME 2

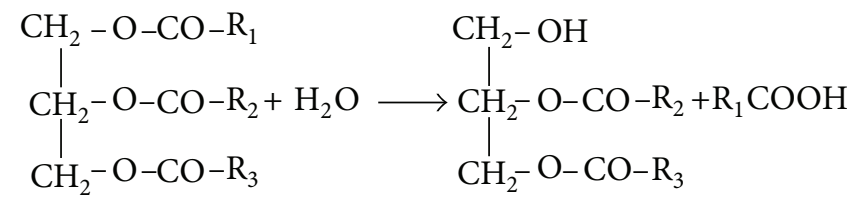

Triglyceride Water Diglyceride FFA

SCHEMe 3

$$
\mathrm{R}_{1}-\mathrm{COOH}+\mathrm{ROH} \longrightarrow \mathrm{R}-\mathrm{O}-\mathrm{CO}-\mathrm{R}_{1}+\mathrm{H}_{2} \mathrm{O}
$$

FFA (alcohol) Fatty acid ester (water)

SCHEMe 4

2.3. Side Reaction 2 (Hydrolysis Reaction). Water generated either from vegetable oil or formed during saponification reaction will hydrolyze triglyceride to form more free fatty acid. The hydrolysis reaction is given as shown in Scheme 3 .

Various methods of biodiesel production through transesterification of waste cooking oil are shown in Table 1.

2.4. Esterification. In order to eliminate saponification reaction (formation of soap when FFA reacts with homogenous base catalyst) vegetable oil can be pretreated with acid catalyst, which esterifies free fatty acid to form esters of free fatty acid (biodiesel). This reaction is very much useful when raw material contains high percentage of free fatty acid (esterification of free fatty acid to form free acid esters). But this reaction is slower than base catalyzed transesterification reaction. The esterification reaction is given as shown in Scheme 4.

\section{Factors Affecting the Production of Biodiesel from Waste Cooking Oil}

3.1. Water Content. Water content in waste cooking oil will accelerate the hydrolysis reaction and simultaneously reduce the amount of ester formation [20]. Water content should not always exceed $0.5 \%$ to obtain $90 \%$ yield of biodiesel and it is more critical for an acid-catalyzed reaction than basecatalyzed reaction [49]. When acid catalysts are used for esterification of free fatty acid to form esters, water is obtained as by-product. Water will naturally inhibit acid-catalyzed reaction [8] and also its presence in the product will decrease the efficiency of engines. In most cases waste cooking oil is preheated to $120^{\circ} \mathrm{C}$ to evaporate water molecules [50] and those water molecules present in the product can be removed by using anhydrous sodium sulfate $\left(\mathrm{Na}_{2} \mathrm{SO}_{4}\right)$ [51] or magnesium sulfate anhydrous [15]. Some enzymes require certain amount of water to be active, which is lesser than monolayer amount of water molecules around the enzyme molecules [52]; if water present in raw material exceeds this limit, it will decrease the conversion by deactivating the lipase [33].

3.2. Free Fatty Acid. Waste cooking oil contains high free fatty acid content than the fresh cooking oils [44]. Hence, it is know that higher free fatty acid contents will lead to formation of soap and water. Similarly, if free fatty acid content exceeds $3 \%$, transesterification reaction will not proceed even with homogenous base catalyst [51]. Hence this problem could be solved by using heterogeneous catalyst $[12,27,53]$ and also on pretreatment with acid homogenous catalyst $[18,54-56]$ or heterogeneous catalyst [11, 17, 57-59] to esterify the free fatty acid to form free fatty acid ester. 


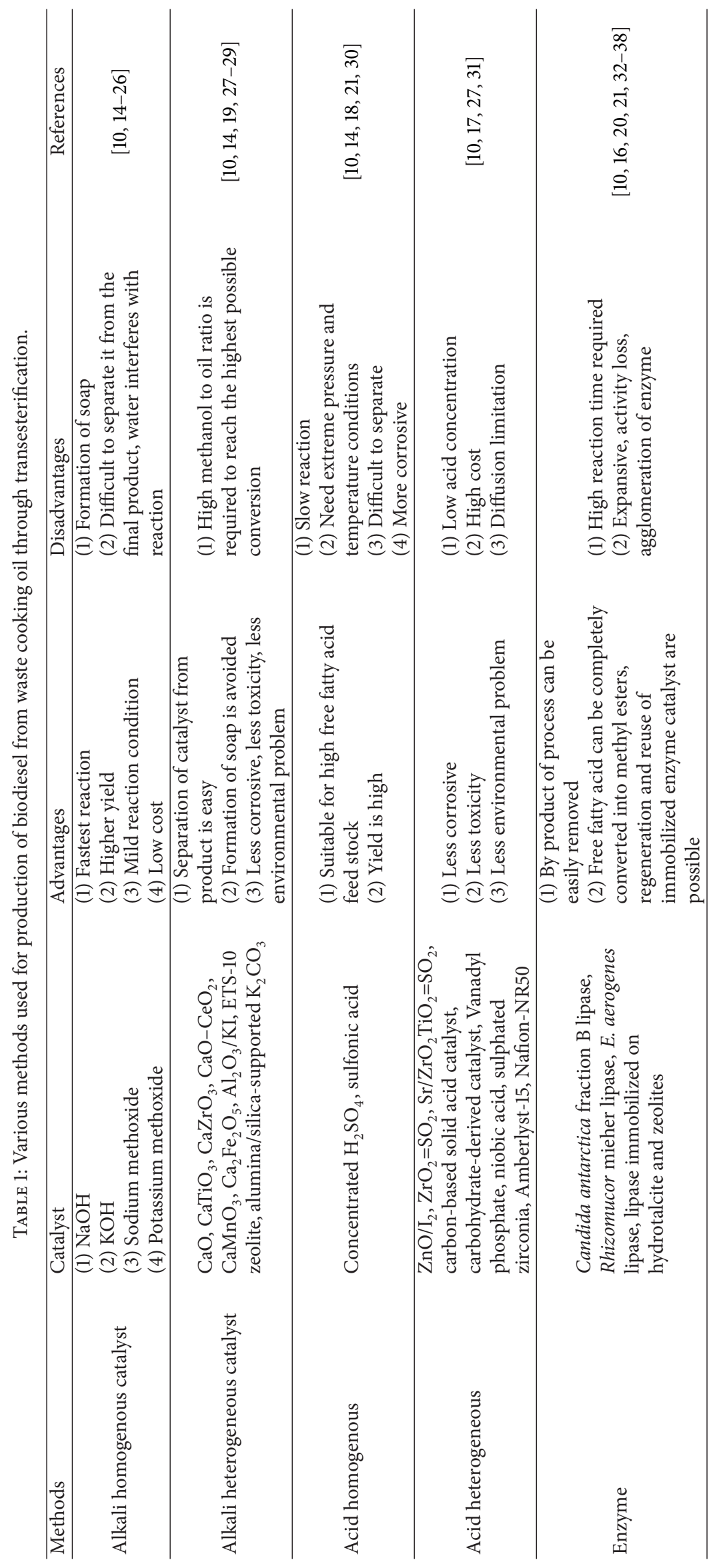


Usually, the acid-catalyzed reaction rate is low and high reaction conditions are required [10]. Soaps formed while neutralizing free fatty acid using homogenous base catalyst can be converted back to free fatty acid by adding phosphoric acid to decanted glycerol and soap mixture obtained from final product [6].

3.3. Type of Alcohol. In most cases, methanol is used for the production of biodiesel, because recovery of methanol from the final product is much easier [58]. Yield of biodiesel obtained from waste cooking oil using methanol is higher than other alcohols (ethanol, butanol) $[45,46]$ and viscosity of biodiesel obtained using methanol is lesser than that of biofuel obtained from other alcohols [46]. The cost of methanol is lesser than that of other alcohols, but ethanol is less toxic than methanol [21]. Ethanol can be obtained from renewable source [39]. When ethanol or isopropanol is used it will form azeotrope with water, which inturn makes difficulty in separation of water from alcohol during distillation process [55]. In some cases, $\mathrm{i}$-butanol or t-butanol is added as solvent to the reaction mixture to avoid the inhibition of lipase by methanol or glycerol. But in most of enzymatic reactions, ethanol is being used instead of methanol $[33,60]$.

3.4. Alcohol to Oil Ratio. To produce three moles of alkyl esters, three moles of alcohol and one mole of triglyceride are required [19]. Alcohol to oil ratio always has positive, effect on biofuel conversion [61]. According to Le Chateliers principle, the rate of formation of product increases as reactant concentration is increased. Therefore, if the concentration of alcohol is increased automatically, the rate of product formation will be accelerated. Further increase in the molar ratio of alcohol to oil will increase the product formation. The recovery of glycerol and unreacted methanol becomes tedious [21, 56] and also increases the cost of product biodiesel by increasing its posttreatment cost. Hossain et al. [46] used methanol for transesterification of waste sunflower oil and studied using various molar ratio of alcohol to oil with $\mathrm{NaOH}$ catalyst and found that $6: 1$ molar ratios of alcohol to oil gave the highest yield of $99.5 \%$ methyl ester [15]. But when they studied the transesterification of waste canola oil using 1:1 molar ratio of methanol to oil, the yield was reported to be $49.5 \%$ [46].

3.5. Catalyst Type. In recent years, various catalysts (homogenous, heterogeneous, and enzyme catalyst) had been tested for the production of alkyl esters. Vicente et al. [14] studied using various base catalysts for production of alkyl esters and concluded that $\mathrm{NaOH}$ is the fastest catalysts among the catalysts used $(\mathrm{NaOH}, \mathrm{KOH}$, sodium methoxide, the potassium methoxide). Refaat et al. [43] reported that $\mathrm{KOH}$ gives the highest yield for feedstock he had used. Some of the researchers used concentrated sulfuric acid as acid catalyst $[62,63]$, but it requires high reaction time and high reaction condition. Even 1\% (mole) can give up to $99 \%$ conversion [21]. In the case of raw material having higher free fatty acid content, acid catalyst (homogenous/heterogeneous) are used for esterification reaction [19]. Acid catalyst can be used simultaneously for both esterification and transesterification reactions [49]. One of the main disadvantages in using homogenous catalyst is the recovery of catalyst from the final product and formation of soap [14]. To overcome this issue most of researchers used heterogeneous catalyst because heterogeneous catalyst is not affected by free fatty acid and moisture present in the raw material [64]. Enzyme catalytic reaction is the slowest reaction among all other catalytic reactions. They can be used for both esterification and transesterification processes. Though the separation of product is easier while using enzyme catalyst, preparation of enzyme catalyst is most critical $[21,52]$.

3.6. Catalyst Concentration. In the absence of catalyst, conversion of waste cooking oil into biofuel requires high temperature conditions [65]. When catalyst concentration is increased, the yield of the product will also increase. This is due to enhancement in rate of reaction. However, the conversion decreases with excess catalyst concentration, which may be due to increased viscosity of the reaction mixture [66]. Many researchers studied by varying the catalyst concentration and also optimized the concentration of catalyst based on product yield and catalyst recovery. Chen et al. [59] used $\mathrm{CuVOP}$ and reported that $1.5 \%$ of catalyst concentration is most effective for the production of biodiesel from soya bean oil. Increase of enzyme concentration will increase the percentage conversion. But beyond the certain limit, agglomeration of enzyme will take place. It will decrease the active site available on substrate [33, 34]. Dehkordi and Ghasem [67] studied with heterogeneous solid catalysts comprising $\mathrm{CaO}$ - and $\mathrm{ZrO}_{2}$-mixed oxides, with different molar ratios of $\mathrm{Ca}$ and $\mathrm{Zr}$. It was reported that by increasing $\mathrm{Ca} / \mathrm{Zr}$ ratio, biodiesel yield was increased. But the stability of catalyst was decreased [67]. Hence the optimum catalyst concentration would vary depending upon the type of raw material and catalyst [19].

3.7. Stirrer Speed. The mixing of reactants is very important to achieve completion of transesterification reaction and also it increases the yield of product [68]. Agitation increases the collision between the particles and diffusion of one reactant into another, thorough mixing of catalyst with reactants and rate of reaction. Increase in stirrer speed will shorten the reaction time [53] and increase the conversion [69]. Beyond certain speed of stirrer, there would not be significant rise in the yield. Therefore, optimization of stirrer speed is necessary for different raw materials based on the different physical properties. Using enzyme catalyst or heterogeneous porous catalyst, the reactants have to diffuse from bulk liquid to surface of catalyst and further into interior surface of catalyst. Kumari et al. [33] found out that there is increase in conversion by increasing the stirrer speed from 100 to $200 \mathrm{rpm}$. But at $250 \mathrm{rpm}$, there was no significant increase in the conversion because of shearing in the enzyme molecules. Hence, it was suggested that $200 \mathrm{rpm}$ was the optimum speed for production of biodiesel using enzymatic reaction.

3.8. Temperature. Temperature has significant influence on transesterification reaction [72]. If the reaction temperature is increased, then the rate of reaction and yield of product will also tend to increase $[19,53]$. The temperature should not 


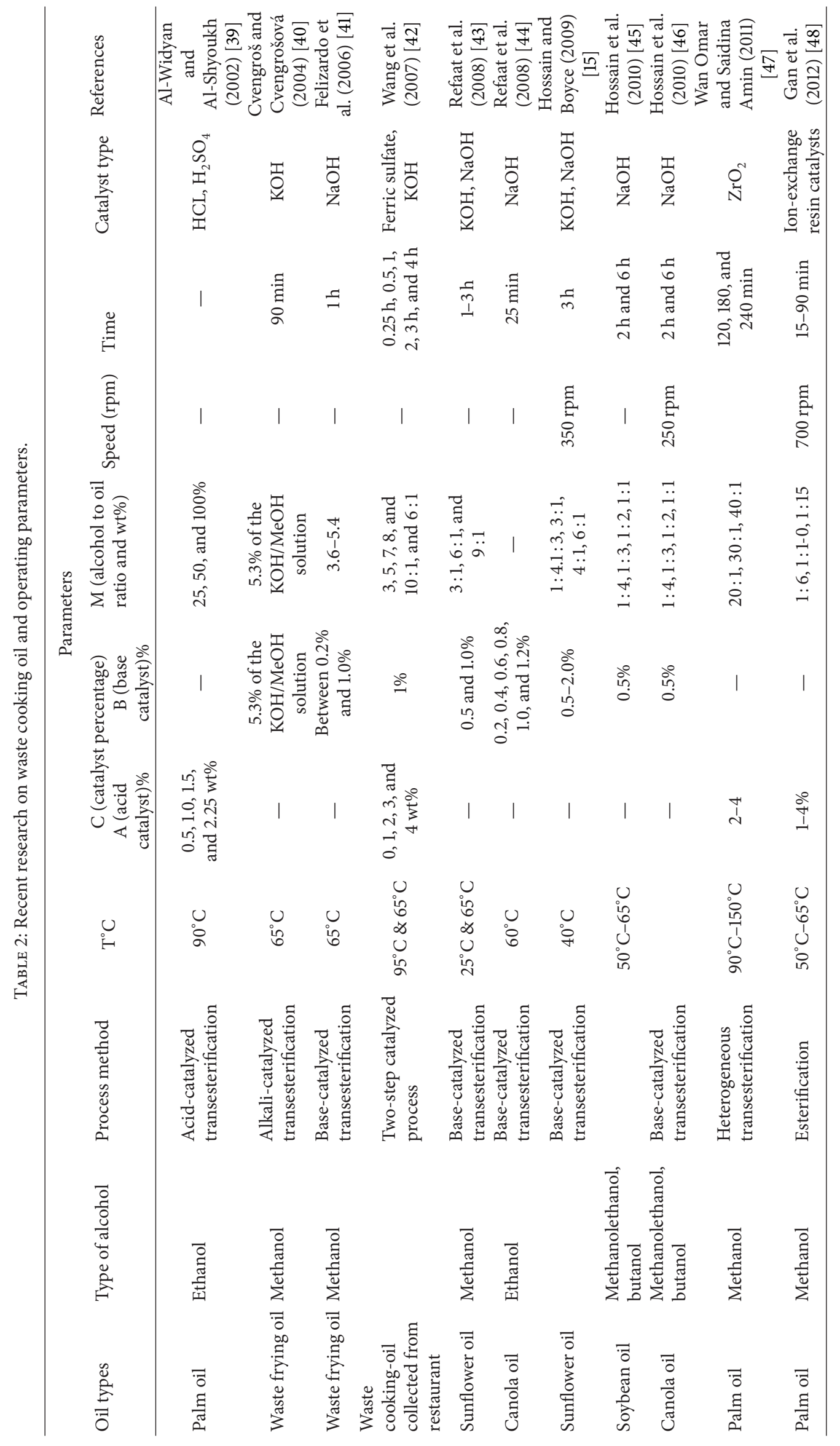




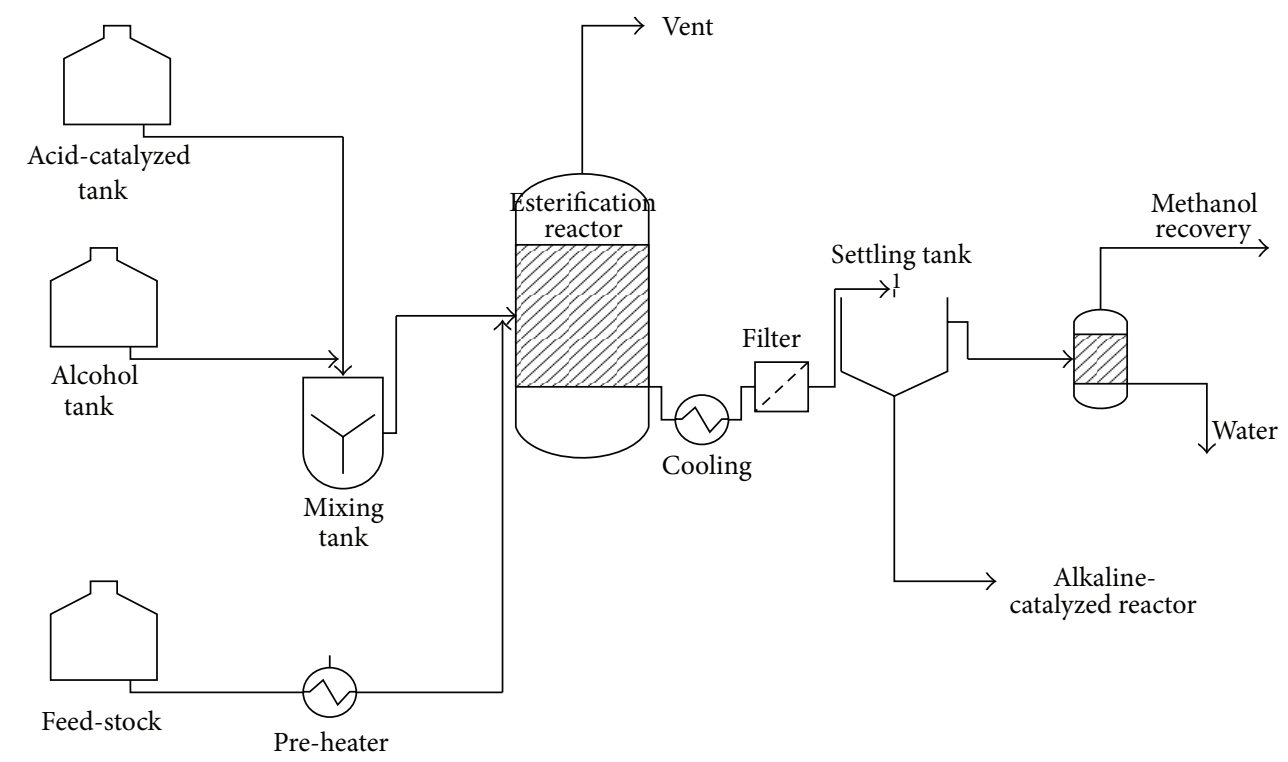

FIGURE 4: Pretreatment of high free fatty acid feed-stock with acid-catalyzed reactor-process I [70, 71].

exceed the boiling point of alcohol. This will avoid vaporization of alcohol [64]. But if the reaction temperature is maintained below $50^{\circ} \mathrm{C}$, then the viscosity of biodiesel will increase [73]. In some cases, waste cooking oil is preheated to $120^{\circ} \mathrm{C}$ to remove water particles present in the raw material and then cooled to $60^{\circ} \mathrm{C}[74]$. For an enzymatic reaction, conversion increases over a temperature range of $30-55^{\circ} \mathrm{C}$. In case of lipase as catalyst, Jatropha oil reported maximum conversion at $55^{\circ} \mathrm{C}$ [33] and for cotton seed oil maximum conversion was obtained at $50^{\circ} \mathrm{C}[46,60]$. Freedman et al. [62] found that there was no difference in conversion for temperatures $45^{\circ} \mathrm{C}$ and $60^{\circ} \mathrm{C}$. But at $32^{\circ} \mathrm{C}$, conversion was much lower than conversion obtained at $45^{\circ} \mathrm{C}$ and $60^{\circ} \mathrm{C}$. After 4 hours, conversion at $32^{\circ} \mathrm{C}$ was slightly higher than conversion obtained at other temperatures [63]. Refaat et al. [43] studied fresh and waste cooking oil from both domestic and commercial sources and reported highest yield at $65^{\circ} \mathrm{C}$ for all the feed stocks using $\mathrm{KOH}$ catalyst. Chen et al. [75] found that the reaction time was reduced significantly to get maximum yield of biodiesel by using of microwave heating.

3.9. Reaction Time. When the reaction was carried out for a longer time, even $99 \%$ of yield could be obtained, but it depends on the availability of reactants in the reaction mixture. If the reaction parameters are not properly adjusted, there are possibilities for the backward reaction, which will decrease the yield of product $[45,76]$. For lipase-catalyzed reaction, time required varies over a range of 7-48 hours [60]. Kapilakarn and Peugtong [73] found that reaction time also affects the product cost. Al-Widyan and Al-Shyoukh [39] reported that when the reaction time increases, specific gravity of the product decreases in an exponential manner and ends with an asymptotic value with respect to time. Refaat et al. [43] obtained a yield of $96.10 \%$ for $1 \mathrm{~h}$ duration and for reaction time $>1 \mathrm{~h}<3 \mathrm{~h}$, it was reported that there was no significant increase in biodiesel yield (96.350\%). Hence, reaction time should be optimized to reduce the production cost.

3.10. $\mathrm{pH} . \mathrm{pH}$ is not a major factor, when base/acid catalyst are used in the reaction. When lipase was used as catalyst, $\mathrm{pH}$ needs to be considered, because at lower or higher $\mathrm{pH}$ value, enzymes may decompose. Devanesan et al. [38] studied biodiesel production from Jatropha oil using immobilized Pseudomonas fluorescence and studied the effect of $\mathrm{pH}$ and concluded that $\mathrm{pH}$ value of 7 is optimum for production for biodiesel.

\section{Process Description}

If the acid value of waste cooking oil exceeds $1-2 \mathrm{mg} \mathrm{KOH} / \mathrm{mg}$ of feed stock [8, 17, 18, 54], then pretreatment of waste cooking oil is required before it gets reacted with alkaline base catalyst.

4.1. Process I. Waste cooking oil may contain particulate matter and other impurities. Such impurities are removed by allowing the waste cooking oil through the filter. Feed stock oils are usually preheated to $60^{\circ} \mathrm{C}$ by heat exchangers.

Alcohol and acid catalysts are properly mixed in mixer before they were allowed into the esterification reactor. The mixing temperature is usually maintained at $60^{\circ} \mathrm{C}$ [68]. Catalyst mixture and preheated feedstock are allowed into the esterification reactor. Esterification reaction was carried out between 80 and $90^{\circ} \mathrm{C}$ and at 1 atmospheric pressure. Products from esterification reactor were cooled to $45^{\circ} \mathrm{C}$, and catalyses are removed or neutralized before allowing into the settling tank to remove the methanol and water mixture. From the top of the settling tank, methanol and water mixture is removed and taken to distillation column to separate methanol from methanol water mixture and methanol is reused. The bottom product of separating vessel is taken to process II for 


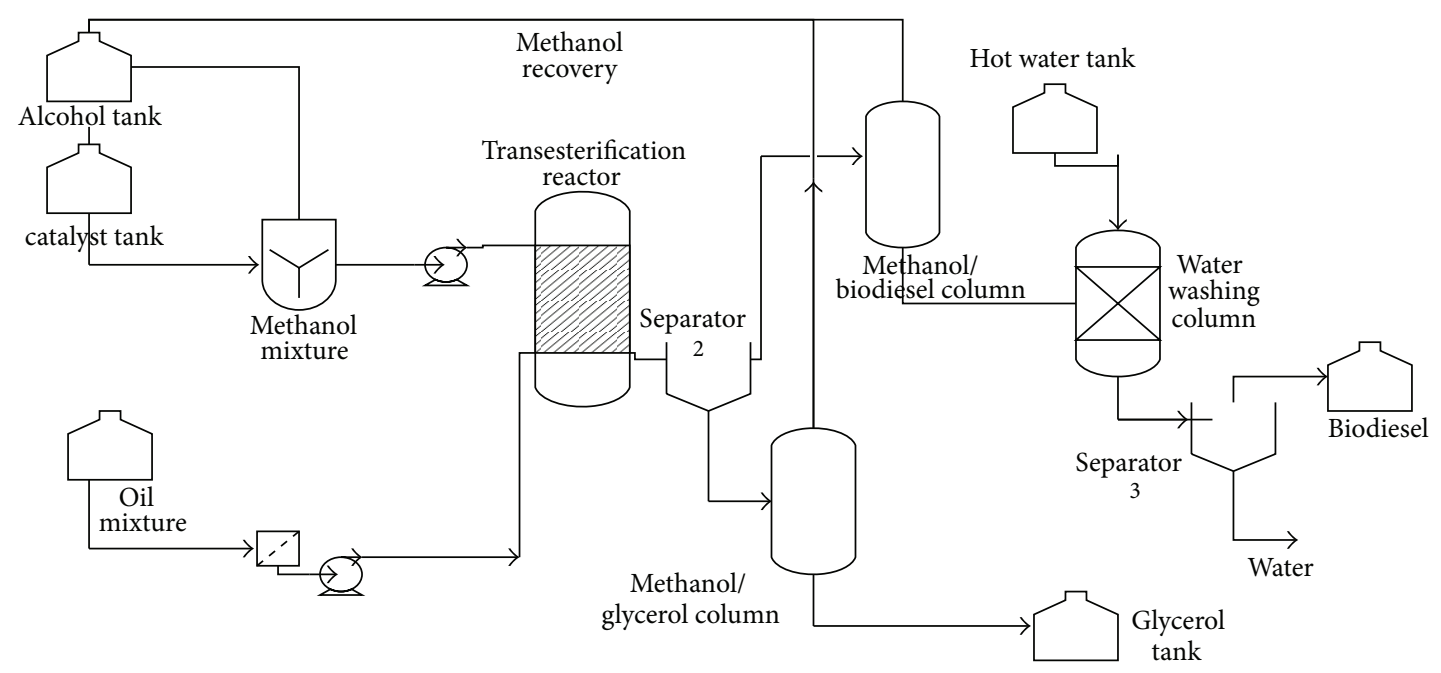

FIGURE 5: Alkali-catalyzed treatment of pretreated waste cooking oil-process II [70, 71].

transesterification reaction. Schematic representation of the process I is shown in Figure 4.

4.2. Process II. Catalyst and alcohol are mixed in the mixer and products obtained from process I are taken into the transesterification reaction column along with catalyst and alcohol mixture. Reactor temperature is usually maintained at $65^{\circ} \mathrm{C}, 1$ atmospheric pressure, and 1:6 molar ratio of oil to alcohol. Products of transesterification reactor are feed into separator 2. From the separation tank, biodiesel and alcohol mixture is distilled to separate methanol and biodiesel. Methanol from distillation column is recycled and reused. Biodiesel is washed with hot water and sent to separator to remove water and biodiesel. From the third separator tank, biodiesel is sent to storage tank. Bottoms of second separator section are moved to the alcohol and glycerol distillation column. From the top of distillation column methanol is recycled. Bottom product of distillation column is taken as byproduct. Schematic representation of the process II is shown in Figure 5.

The recent research works on various waste cooking oils under different operating parameters as shown in Table 2.

\section{Conclusion}

Cost of biodiesel can be reduced by using waste cooking oil as feed stock. High fatty acid content in waste cooking oil could be reduced by pretreating waste cooking oil with acid catalyst. Water produced during the esterification process can inhibit acid catalyst, and this can be eliminated by stepwise reaction mechanism. Methanol is the most suitable alcohol because of its low cost and easy separation from biofuel. Methanol to oil ratio for the acid-catalyzed reaction depends on amount of free fatty acid. For base-catalyzed reaction, $6: 1$ is optimum ratio for transesterification reaction. Concentration of catalyst depends on nature of catalyst used: either heterogeneous or homogenous. Stirrer speed helps to enhance rate of reaction. In most cases, optimum speed of stirrer was maintained in the range of 200-250 rpm.

\section{References}

[1] P. K. Gupta, R. Kumar, B. S. Panesar, and V. K. Thapar, "Parametric studies on bio-diesel prepared from rice bran oil," CIGR E-Journal, vol. 9, EE 06-007, 2007.

[2] O. J. Alamu, T. A. Akintola, C. C. Enweremadu, and A. E. Adeleke, "Characterization of palm-kernel oil biodiesel produced through $\mathrm{NaOH}$-catalysed transesterification process," Scientific Research and Essays, vol. 3, no. 7, pp. 308-311, 2008.

[3] S. Fariku, A. E. Ndonya, and P. Y. Bitrus, "Biofuel characteristics of beniseed (Sesanum indicum) oil," African Journal of Biotechnology, vol. 6, no. 21, pp. 2442-2443, 2007.

[4] J. Connemann and J. Fischer, "Biodiesel processing technologies," in Proceedings of the International Liquid Biofuels Congress, July 1998.

[5] F. Ullah, A. Nosheen, I. Hussain, and A. Bano, "Base catalyzed transesterification of wild apricot kernel oil for biodiesel production," African Journal of Biotechnology, vol. 8, no. 14, pp. 3289-3293, 2009.

[6] G. E. Diwani, N. K. Attia, and S. I. Hawash, "Development and evaluation of biodiesel fuel and by-products from jatropha oil," International Journal of Environmental Science and Technology, vol. 6, no. 2, pp. 219-224, 2009.

[7] F. O. Licht, “The Global Renewable Fuels Alliance is a non-profit organization dedicated to promoting biofuel friendly policies internationally," Global Renewable Fuels Alliance, 2011.

[8] M. Canakci, "The potential of restaurant waste lipids as biodiesel feedstocks," Bioresource Technology, vol. 98, no. 1, pp. 183-190, 2007.

[9] B. Supple, R. Howard-Hildige, E. Gonzalez-Gomez, and J. J. Leahy, "The effect of steam treating waste cooking oil on the yield of methyl ester," Journal of the American Oil Chemists' Society, vol. 79, no. 2, pp. 175-178, 2002.

[10] D. Y. C. Leung, X. Wu, and M. K. H. Leung, "A review on biodiesel production using catalyzed transesterification," Applied Energy, vol. 87, no. 4, pp. 1083-1095, 2010. 
[11] B. Rice, A. Fröhlich, and R. Leonard, "Bio-diesel production from camelina oil, waste cooking oil and tallow," The Science of Farming and Food, 1998.

[12] Y. Feng, Q. Yang, X. Wang, Y. Liu, H. Lee, and N. Ren, "Treatment of biodiesel production wastes with simultaneous electricity generation using a single-chamber microbial fuel cell," Bioresource Technology, vol. 102, no. 1, pp. 411-415, 2011.

[13] The Endress+Hauser Group, http://www.au.endress.com/.

[14] G. Vicente, M. Martınez, and J. Araci, "Integrated biodiesel production: a comparison of different homogeneous catalysts systems," Bioresource Technology, vol. 92, pp. 297-305, 2004.

[15] A. B. M. S. Hossain and A. N. Boyce, "Biodiesel production from waste sunflower cooking oil as an environmental recycling process and renewable energy," Bulgarian Journal of Agricultural Science, vol. 15, no. 4, pp. 312-317, 2009.

[16] A. B. M. S. Hossain, B. A. Nasrulhaq, A. Salleh, and S. Chandran, "Biodiesel production from waste soybean oil biomass as renewable energy and environmental recycled process," African Journal of Biotechnology, vol. 9, no. 27, pp. 4233-4240, 2010.

[17] G. Corro, N. Tellez, E. Ayala, and A. Marinez-Ayala, "Twostep biodiesel production from Jatropha curcas crude oil using $\mathrm{SiO}_{2} \cdot \mathrm{HF}$ solid catalyst for FFA esterification step," Fuel, vol. 89, no. 10, pp. 2815-2821, 2010.

[18] S. Liu, T. McDonald, and Y. Wang, "Producing biodiesel from high free fatty acids waste cooking oil assisted by radio frequency heating," Biotechnology Advances, vol. 28, no. 4, pp. 500$518,2010$.

[19] B. K. Highina, I. M. Bugaje, and B. Umar, "Biodiesel production from Jatropha caucus oil in a batch reactor using zinc oxide as catalyst," Journal of Petroleum Technology and Alternative Fuels, vol. 2, no. 9, pp. 146-149, 2011.

[20] N. Arun, M. Sampath, S. Siddharth, and R. A. Prasaanth, "Experimental Studies of base catalyzed transesterification of karanja oil," Journal of Energy and Environment, vol. 2, no. 2, pp. 351-356, 2011.

[21] J. M. Marchetti, V. U. Miguel, and A. F. Errazu, "Possible methods for biodiesel production," Renewable and Sustainable Energy Reviews", vol. 11, pp. 1300-1311, 2007.

[22] D. Y. C. Leung and Y. Guo, "Transesterification of neat and used frying oil: optimization for biodiesel production," Fuel Processing Technology, vol. 87, no. 10, pp. 883-890, 2006.

[23] R. Guzatto, T. L. De Martini, and D. Samios, "The use of a modified TDSP for biodiesel production from soybean, linseed and waste cooking oil," Fuel Processing Technology, vol. 92, no. 10, pp. 2082-2088, 2011.

[24] G. Vicente, M. Martınez, and J. Aracil, "Integrated biodiesel production: a comparison of different homogeneous catalysts systems," Bioresource Technology, vol. 92, pp. 297-305, 2004.

[25] Y. G. Wu, Y. Lin, and C. T. Chang, "Combustion characteristics of fatty acid methyl esters derived from recycled cooking oil," Fuel, vol. 86, pp. 2810-2816, 2007.

[26] A. Okullo, A. K. Temu, P. Ogwok, and J. W. Ntalikwa, "The physico-chemical properties of jatropha and castor oils," International Journal of Renewable Energy Research, vol. 2, no. 1, pp. 47-52, 2012.

[27] J. Zhang, S. Chen, R. Yang, and Y. Yan, "Biodiesel production from vegetable oil using heterogenous acid and alkali catalyst," Fuel, vol. 89, no. 10, pp. 2939-2944, 2010.

[28] P. L. Boeya, S. Ganesana, G. P. Maniamb, and M. Khairuddeana, "Catalysts derived from waste sources in the production of biodiesel using waste cooking oil," Catalysis Today, vol. 190, pp. 117-121, 2012.
[29] N. Taufiqurrahmi, A. R. Mohamed, and S. Bhatia, "Production of biofuel from waste cooking palm oil using Nano crystalline zeolite as catalyst: process optimization studies," Bioresource Technology, vol. 102, pp. 10686-10694, 2011.

[30] S. Zhenga, M. Katesb, M. A. Dubea, and D. D. Mc Lean, "Acid-catalyzed production of biodiesel from waste frying oil," Biomass and Bioenergy, vol. 30, pp. 267-272, 2006.

[31] W. N. N. W. Omar and N. A. S. Amin, "Biodiesel production from waste cooking oil over alkaline modified zirconia catalyst," Fuel Processing Technology, vol. 92, pp. 2397-2405, 2011.

[32] G. Perez, Analysis of enzymatic alcoholic reaction with vegetables oils [M.S. thesis], 2003.

[33] A. Kumari, P. Mahapatra, V. K. Garlapati, and R. Banerjee, "Enzymatic transesterification of Jatropha oil," Biotechnology for Biofuels, vol. 2, article 1, 2009.

[34] R. MacEiras, A. Cancela, M. Vega, and M. C. Márquez, "Enzymatic alholysis for biodiesel production from waste cooking oil," in Chemical Engineering Transactions, vol. 19, pp. 103-107.

[35] M. Iso, B. Chen, M. Eguchi, T. Kudo, and S. Shrestha, "Production of biodiesel fuel from triglycerides and alcohol using immobilized lipase," Journal of Molecular Catalysis B, vol. 16, no. 1, pp. 53-58, 2001.

[36] B. Balasubramaniam, A. S. Perumal, J. Jayaraman, J. Mani, and P. Ramanujam, "Comparative analysis for the production of fatty acid alkyl esterase using whole cell biocatalyst and purified enzyme from Rhizopus oryzae on waste cooking oil (sunflower oil)," Waste Management, vol. 32, pp. 1539-1547, 2012.

[37] F. Yagiz, D. Kazan, and A. N. Akin, "Biodiesel production from waste oils by using lipase immobilized on hydrotalcite and zeolites," Chemical Engineering Journal, vol. 134, no. 1-3, pp. 262-267, 2007.

[38] M. G. Devanesan, T. Viruthagiri, and N. Sugumar, "Transesterification of Jatropha oil using immobilized Pseudomonas fluorescens," African Journal of Biotechnology, vol. 6, no. 21, pp. 2497-2501, 2007.

[39] M. I. Al-Widyan and A. O. Al-Shyoukh, "Experimental evaluation of the transesterification of waste palm oil into biodiesel," Bioresource Technology, vol. 85, no. 3, pp. 253-256, 2002.

[40] J. Cvengroš and Z. Cvengrošová, "Used frying oils and fats and their utilization in the production of methyl esters of higher fatty acids," Biomass and Bioenergy, vol. 27, no. 2, pp. 173-181, 2004.

[41] P. Felizardo, M. J. Neiva Correia, I. Raposo, J. F. Mendes, R. Berkemeier, and J. M. Bordado, "Production of biodiesel from waste frying oils," Waste Management, vol. 26, no. 5, pp. 487494, 2006.

[42] Y. Wang, S. O. Pengzhan Liu, and Z. Zhang, "Preparation of biodiesel from waste cooking oil via two-step catalyzed process," Energy Conversion and Management, vol. 48, no. 1, pp. 184-188, 2007.

[43] A. A. Refaat, N. K. Attia, H. A. Sibak, S. T. El Sheltawy, and G. I. ElDiwani, "Production optimization and quality assessment of biodiesel from waste vegetable oil," International Journal of Environmental Science and Technology, vol. 5, no. 1, pp. 75-82, 2008.

[44] A. B. Chhetri, K. C. Watts, and M. R. Islam, "Waste cooking oil as an alternate feedstock for biodiesel production," Energies, vol. 1, no. 1, pp. 3-18, 2008.

[45] A. B. M. S. Hossain, B. A. Nasrulhaq, A. Salleh, and S. Chandran, "Biodiesel production from waste soybean oil biomass as renewable energy and environmental recycled process," African Journal of Biotechnology, vol. 9, no. 27, pp. 4233-4240, 2010. 
[46] A. B. M. S. Hossain, A. N. Boyce, A. Salleh, and S. Chandran, "Impacts of alcohol type, ratio and stirring time on the biodiesel production from waste canola oil," African Journal of Agricultural Research, vol. 5, no. 14, pp. 1851-1859, 2010.

[47] W. N. N. Wan Omar and N. A. Saidina Amin, "Optimization of heterogeneous biodiesel production from waste cooking palm oil via response surface methodology," Biomass and Bioenergy, vol. 35, no. 3, pp. 1329-1338, 2011.

[48] S. Gan, H. K. Ng, P. H. Chan, and F. L. Leong, "Heterogeneous free fatty acids esterification in waste cooking oil using ionexchange resins," Fuel Processing Technology, vol. 102, pp. 67-72, 2012.

[49] E. Lotero, Y. Liu, D. E. Lopez, K. Suwannakarn, D. A. Bruce, and J. G. Goodwin, "Synthesis of biodiesel via acid catalysis," Industrial and Engineering Chemistry Research, vol. 44, no. 14, pp. 5353-5363, 2005.

[50] M. Ahmad, S. Rashid, M. A. Khan, M. Zafar, S. Sultana, and S. Gulzar, "Optimization of base catalyzed transesterification of peanut oil biodiesel," African Journal of Biotechnology, vol. 8, no. 3, pp. 441-446, 2009.

[51] M. Ahmad, S. Ahmed, F. U. Hassan et al., "Base catalyzed transesterification of sunflower oil biodiesel," African Journal of Biotechnology, vol. 9, no. 50, pp. 8630-8635, 2010.

[52] S. Shah, S. Sharma, and M. N. Gupta, "Enzymatic transesterification for biodiesel production," Indian Journal of Biochemistry and Biophysics, vol. 40, no. 6, pp. 392-399, 2003.

[53] S. T. Jiang, F. J. Zhang, and L. J. Pan, "Sodium phosphate as a solid catalystfor biodiesel preparation," Brazilian Journal of Chemical Engineering, vol. 27, no. 1, pp. 137-144, 2010.

[54] S. A. El Sherbiny, A. A. Refaat, and S. T. El Sheltawy, "Production of biodiesel using the microwave technique," Journal of Advanced Research, vol. 1, no. 4, pp. 309-314, 2010.

[55] J. Van Gerpen, "Biodiesel processing and production," Fuel Processing Technology, vol. 86, no. 10, pp. 1097-1107, 2005.

[56] G. Knothe and K. R. Steidley, "A comparison of used cooking oils: a very heterogeneous feedstock for biodiesel," Bioresource Technology, vol. 100, no. 23, pp. 5796-5801, 2009.

[57] H. Muthu, V. S. Selvabala, T. K. Varathachary, D. K. Selvaraj, J. Nandagopal, and S. Subramanian, "Synthesis of biodiesel from neem oil using sulfated zirconia via tranesterification," Brazilian Journal of Chemical Engineering, vol. 27, no. 4, pp. 601-608, 2010.

[58] M. Mathiyazhagan, A. Ganapathi, B. Jaganath, N. Renganayaki, and N. Sasireka, "Production of biodiesel from non-edible plant oils having high FFA content," International Journal of Chemical and Environmental Engineering, vol. 2, no. 2, pp. 119-122, 2011.

[59] L. Chen, P. Yin, X. Liu et al., "Biodiesel production over copper vanadium phosphate," Energy, vol. 36, no. 1, pp. 175-180, 2011.

[60] D. Royon, M. Daz, G. Ellenrieder, and S. Locatelli, "Enzymatic production of biodiesel from cotton seed oil using t-butanol as a solvent," Bioresource Technology, vol. 98, no. 3, pp. 648-653, 2007.

[61] I. Noshadi, N. A. S. Amin, and R. S. Parnas, "Continuous production of biodiesel from waste cooking oil in a reactive distillation column catalyzed by solid heteropolyacid: optimization using response surface methodology (RSM)," Fuel, vol. 94, pp. 156-164, 2012.

[62] B. Freedman, R. Butterfield, and E. Pryde, “Transesterification kinetics of soybean oil," Journal of the American Oil Chemists' Society, vol. 63, no. 10, pp. 1375-1380, 1986.

[63] B. Freedman, E. H. Pryde, and T. L. Mounts, "Variables affecting the yields of fatty esters from transesterified vegetable oils,"
Journal of the American Oil Chemists' Society, vol. 61, no. 10, pp. 1638-1643, 1984.

[64] S. Li, Y. Wang, S. Dong et al., "Biodiesel production from Eruca Sativa Gars vegetable oil and motor, emissions properties," Renewable Energy, vol. 34, no. 7, pp. 1871-1876, 2009.

[65] K. T. Tan, K. T. Lee, and A. R. Mohamed, "Potential of waste palm cooking oil for catalyst-free biodiesel production," Energy, vol. 36, no. 4, pp. 2085-2088, 2011.

[66] A. T. Kiakalaieh, N. A. S. Amin, A. Zarei, and I. Noshadi, "Transesterification of waste cooking oil by heteropoly acid (HPA) catalyst: optimization and kinetic model," Applied Energy, vol. 102, pp. 283-292, 2013.

[67] A. M. Dehkordi and M. Ghasem, "Transesterification of waste cooking oil to biodiesel using $\mathrm{Ca}$ and $\mathrm{Zr}$ mixed oxides as heterogeneous base catalysts," Fuel Processing Technology, vol. 97, pp. 45-51, 2012.

[68] M. Canakci and J. Van Gerpen, "A pilot plant to produce biodiesel from high free fatty acid feedstocks," Transactions of the American Society of Agricultural Engineers, vol. 46, no. 4, pp. 945-954, 2003.

[69] N. A. Adeyemi, A. Mohiuddin, and T. Jameel, "Waste cooking oil transesterification: influence of impeller type, temperature, speed and bottom clearance on FAME yield," African Journal of Biotechnology, vol. 10, no. 44, pp. 8914-8929, 2011.

[70] A. Sivasamy, K. Y. Cheah, P. Fornasiero, F. Kemausuor, S. Zinoviev, and S. Miertus, "Catalytic applications in the production of biodiesel from vegetable oils," ChemSusChem, vol. 2, no. 4, pp. 278-300, 2009.

[71] Y. Zhang, M. A. Dubé, D. D. McLean, and M. Kates, "Biodiesel production from waste cooking oil.1: process design and technological assessment," Bioresource Technology, vol. 89, no. 1, pp. 1-16, 2003.

[72] D. Darnoko and M. Cheryan, "Kinetics of palm oil transesterification in a batch reactor," Journal of the American Oil Chemists' Society, vol. 77, no. 12, pp. 1263-1267, 2000.

[73] K. Kapilakarn and A. Peugtong, "A comparison of costs of biodiesel production from transesterication," International Energy Journal, vol. 8, no. 1, pp. 1-6, 2007.

[74] J. M. Dias, C. A. Ferraz, and M. F. Almeida, "Using mixtures of waste frying oil and pork lard to produce biodiesel," World Academy of Science, Engineering and Technology, vol. 44, 2008.

[75] K. S. Chen, Y. C. Lin, K. H. Hsu, and H. K. Wang, "Improving biodiesel yields from waste cooking oil by using sodium methoxide and a microwave heating system," Energy, vol. 38, pp. 151-156, 2012.

[76] A. A. Refaat, "Different techniques for the production of biodiesel from waste vegetable oil," International Journal of Environmental Science and Technology, vol. 7, no. 1, pp. 183-213, 2010. 


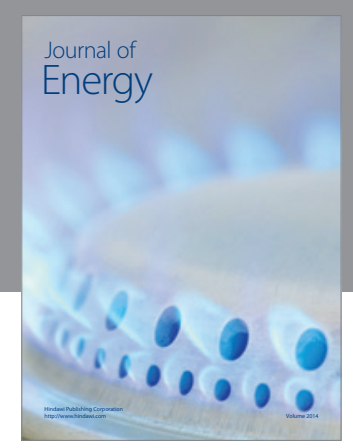

Journal of

Industrial Engineering
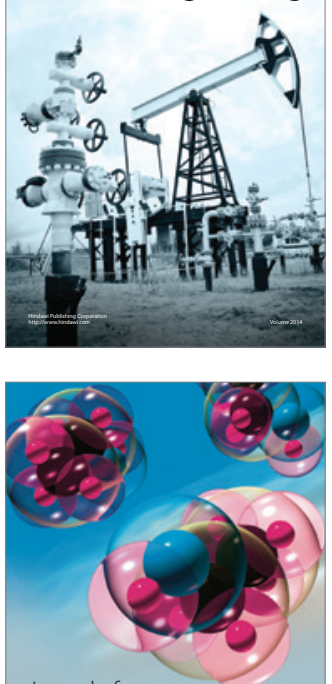

Fuels
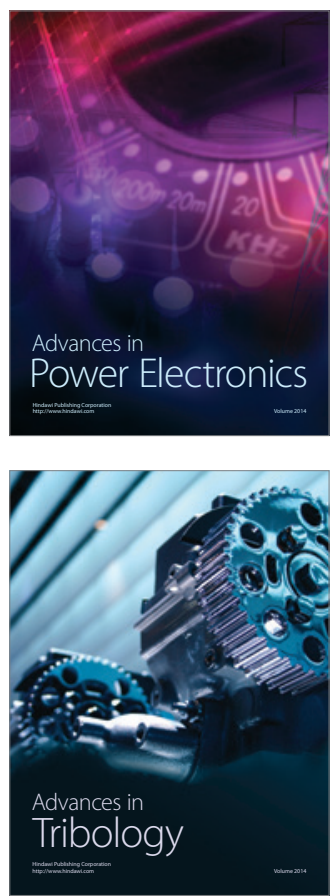

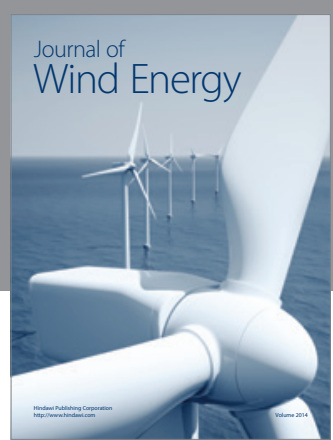

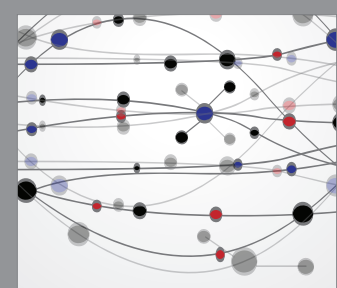

The Scientific World Journal

Submit your manuscripts at http://www.hindawi.com

Journal of

Structures
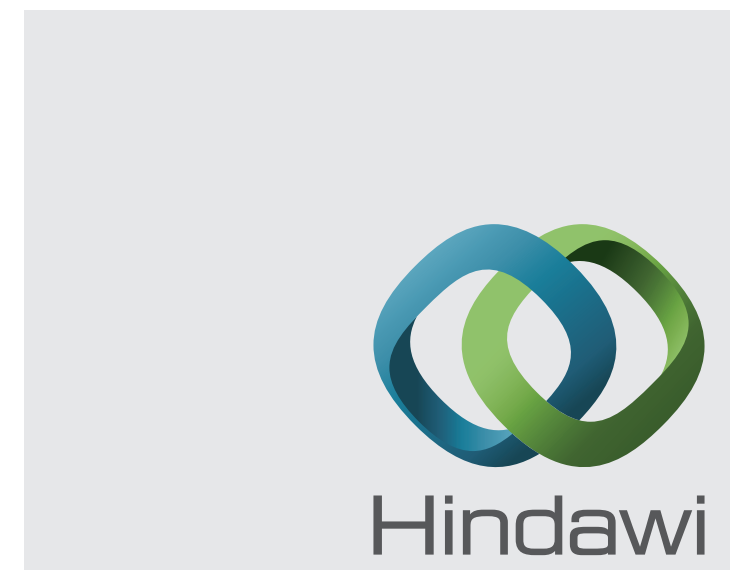

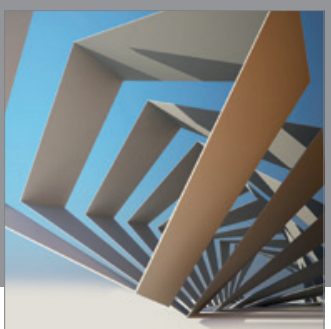

Rotating

Machinery
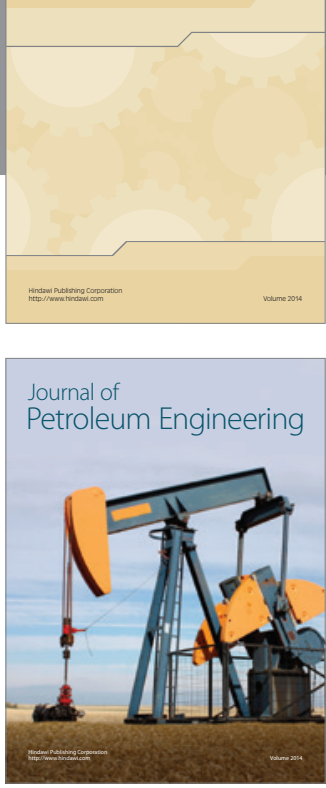

Journal of

Solar Energy
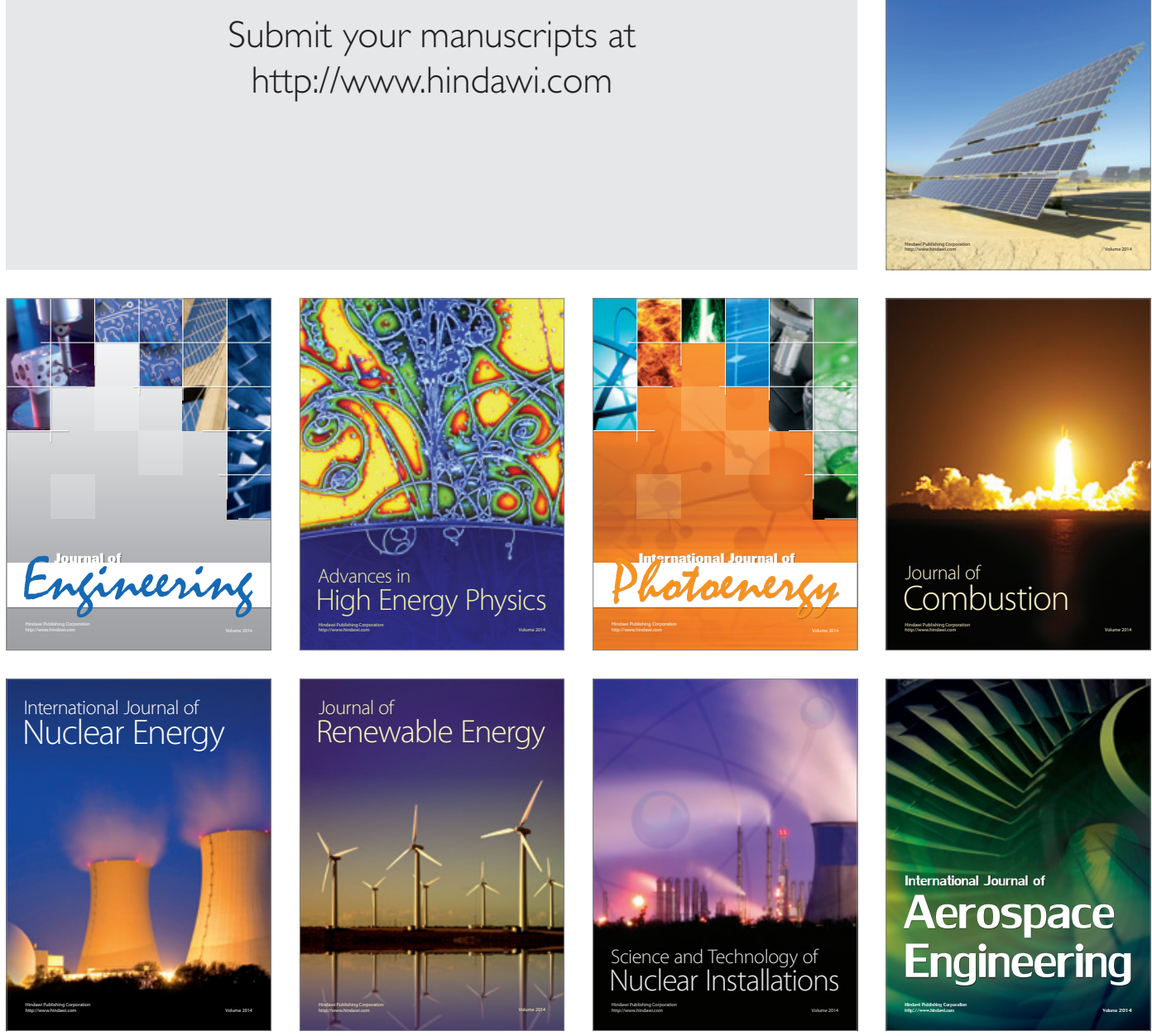